\title{
Perceptions and knowledges about Pediatric Patient safety
}

\author{
Percepções e saberes sobre a segurança do Paciente Pediátrico \\ Percepciones y saber sobre la seguridad del paciente pediátrico
}

\begin{abstract}
Marcia do Carmo Gaita ${ }^{1}$
\end{abstract} Rosane Teresinha Fontana ${ }^{1}$ (i)

1. Universidade Regional integrada do Alto Uruguai e das Missões. Santo Ângelo, RS, Brasil.
Corresponding author:

Rosane Teresinha Fontana.

E-mail: rfontana@san.uri.br

Submitted on 08/27/2017.

Accepted on 06/24/2018.

DOI: 10.1590/2177-9465-EAN-2017-0223

\begin{abstract}
Objectives: To investigate students' conceptions of technical courses on pediatric patient safety; to investigate situations that favour the insecure care in pediatric units and to elaborate a booklet, in order to contribute to the teaching of the safety in the nursing care to the hospitalized child and to the health education to the workers of pediatric units. Method: Qualitative study based on symbolic interactionism. The data were collected in 2015, through a questionnaire to students from technical schools, complemented by systematic observation in two hospital units, located in the northwest of Rio Grande do Sul and treated by the thematic analysis. Results: Failures were reported in drug administration and hand hygiene, among others. To improve safety was suggested adequate organization of the work and higher workload of clinical practice. Conclusion and implications for the practice: Continuing education and more practical classes can help in the construction of knowledge to safe attendance.
\end{abstract}

Keywords: Patient Safety; Protection Systems for Children; Nursing; Teaching; Learning.

\section{Resumo}

Objetivos: Investigar concepções de discentes de cursos técnicos, acerca da segurança do paciente pediátrico; averiguar situações que favorecem o cuidado inseguro em unidades pediátricas e elaborar uma cartilha, de modo a contribuir para o ensino da segurança no cuidado de enfermagem à criança hospitalizada e para a educação em saúde aos trabalhadores de unidades pediátricas. Método: Estudo qualitativo alicerçado no interacionismo simbólico. Os dados foram coletados em 2015 mediante um questionário à discentes de escolas técnicas, complementado pela observação sistemática em duas unidades hospitalares, localizadas ao Noroeste do Rio Grande do Sul e tratados pela análise temática. Resultados: Foram apontadas falhas na administração de medicamentos e na higienização das mãos, entre outras. Para melhorar a segurança, foi sugerido organização adequada do trabalho e maior carga horária de prática clínica. Conclusão e implicações para a prática: Educação permanente e mais aulas práticas podem auxiliar na construção de saberes à assistência segura.

Palavras-chave: Segurança do Paciente; Sistemas de Proteção para Crianças; Enfermagem; Ensino; Aprendizagem.

\section{Resumen}

Objetivos: Investigar concepciones de discentes de cursos técnicos, acerca de la seguridad del paciente pediátrico; averiguar situaciones que favorecen el cuidado inseguro en unidades pediátricas y elaborar una cartilla, de modo a contribuir a la enseñanza de la seguridad en el cuidado de enfermería al niño hospitalizado ya la educación en salud a los trabajadores de unidades pediátricas. Método: Estudio cualitativo basado en el interacionismo simbólico. Los datos fueron recolectados en 2015 mediante un cuestionario a discentes de escuelas técnicas, complementado por la observación sistemática en dos unidades hospitalarias, localizadas al noroeste de Rio Grande do Sul y tratados por el análisis temático. Resultados: Se señalaron fallas en la administración de medicamentos y en la higienización de las manos, entre otras. Para mejorar la seguridad se sugirió una organización adecuada del trabajo y una mayor carga horaria de práctica clínica. Conclusión e implicaciones para la práctica: Educación permanente y más clases prácticas pueden auxiliar en la construcción de saberes a la asistencia segura.

Palabras clave: Seguridad del Paciente; Sistemas de Protección para Niños; Enfermería; Enseñando; Aprendizage. 


\section{INTRODUCTION}

The concern with patient safety is historic. Hippocrates (460 to 370 b.C.), father of medicine, already mentioned Primum non nocere, which means 'first don't cause harm', demonstrating the notion, since that time, that caring could cause some kind of harm. ${ }^{1}$ Florence Nightingale, on the 19th century, wove the following reflection: "it may seem that maybe a strange principal enunciate as the first obligation of a hospital is not to cause harm to the patient"2:v and structured the care model, when acted in the Crimean War/England, attentive to the separation of soldiers by the type of disease, improvements in the place where they were housed and care for their hygiene and comfort. ${ }^{3}$

As Patient Safety, it's understood the reduction, to a minimum acceptable, to the harm risk needed associated to health care. The Ordinance n. 529 from April 1st 2013, ${ }^{4}$ that instituted the National Program of Patient Safety (PNSP), legislates that the Security Culture is configurated under the assumption that all workers assume responsibility for their own safety, by the safety of collegues, patients and family members. It highlights the priority of safety over financial and operational goals and the promotion of organizational learning in the face of incidents, among others.

According to the Implementation comittee for the National Program of Patient's Safety ${ }^{4}$ actions that aim safe care involve proposing and validating protocols, guidelines and manuals about patient safety in infections related to health care; surgical and anesthesiology procedures; prescription, transition, dispensation and administration of medication, blood and blood products; identification processes of patients; communication in the health care envirornment; prevention of falls and pressure ulcers; patient transfers among care points and safety use of equipments and materials.

Unsafe care processes derive from gaps in planning, collaboration, implementation, evaluation and monitoring of interventions. ${ }^{5}$ According to World Health Organization, it's estimated that one in each ten patients in the world is the victim of erros and adverse events that could be avoided in their care. A recent inquiry developed in 2016, based on modifications made in the country's National Health Surveillance System, reports 53.997 incidents related to health care, being most of incidents (50.735) occured in hospitals, sectors of hospitalization (26.977). ${ }^{6}$

A study sought to profile notifications made in pediatric units of a public university hospital of the south of the country, identified 40 notifications a year, being $32 \%$ of light category, $55 \%$ moderated, $5 \%$ serious and $8 \%$ due to factors not related to care. As for type, data showed that $40 \%$ of incidents were associated to medication, $22 \%$ to allergy caused by identification bracelets/risk of falls, $13 \%$ to conduct of unnecessarily fasting the child, $10 \%$ to other complaints, $5 \%$ to venous access and conducts, $3 \%$ to failures in patient identification and $2 \%$ to administrative factors, denoting that the envirornment of pediatric hospitalization presents risk situations and incidents of safety being more recurrent those related to medication and allergy on bracelet use. ${ }^{7}$

To minimize incidents that can occur adverse events, it's necessary the awareness of caretakers, that should being the process of formation. On nursing technician, undergraduate and graduate Program, the apporach of knowledge and skills about the patient's safety culture, turned to technical knowledge and/or as management tool, it is a potential for the individual's engagement in this culture. The same way, institution's Permanent Education in Health processes, this theme must to mainstream all areas of care, and, the use of Information and Communication Technologies and of active methodologies favour, both the apprehension of these knowledge, and its democratization, considering that the workers' participation in this movement, as the protagonist of his/her activity, makes him/her legitimate to expose his/her difficulties related to the theme and to be a co-manager in the search for solutions.

Since teaching in patient safety a new science, it is necessary to transform Pedagogical Projects (PP), to adequate contents and contribute to a formation that corresponds to the contemporary needs that express themselves in the sector. Still it's fragmented the teaching of the theme on screen and, in many scenarios, it lacks deepening and conceptual amplitude. World Health Organization ${ }^{8}$ recommends an incisive approach and provides the Patient safety curriculum guide: multi-professional edition, that brings updates and exemples of insitutions that included in their curriculum and interconnected to different disciplines and areas of knowledge.

According to National Curricular References of Technician Level Professional Education, patient safety is legislated on the function of 'Protection and Prevention', conceptualized as a "set of actions that aim to protect and preserve health, prevent disease and eliminate or minimize risks to the client/patient/community". And among underfunctions that compose the referential are 'Biosafery in health actions", implicated with Work's Health and Safety, involving the infection control and prevention, the proper disposal of fluids and wastes, the processing of articles and the cleaning and disinfection of environments and equipment, as well as the 'Health Work Process Organization', whose competences include 'assessing iatrogenic risks in the execution of technical procedures, in order to eliminate or reduce damages to the client/community". 9:35

Thus, from empirical observations about fragilities of safety care in a pediatric unit during teaching practice of one of the researchers, emerged the motivation to discuss it. Considering that contribute with facilitator models of teaching and health education, about patient safery, can aggregate value to nursing 
and that, training institutions have great responsibility on constructing and acculturation of theme, it is understood that the research has significative relevance. The research aims to give elements for reflection, development of competences and skills and/or change of teacher's behaviors to qualify child's care.

The theme evokes the need of nursing to train scientifically, with ethical commitment and systemic actions of evaluation and prevention, making possible the reduction of unwanted outcomes, as well as the analysis on the quality of care. Up this, the study had the following questions: how students from the nursing technician program perceive and conceive pediatric patient safety? What situations of the pediatri care scenario favour unsafe care?

This study's aim were to investigate theoretical conceptions of nursing technician students, about pediatric patient safety; to investigate situations that favor the insecure care in pediatric units and to elaborate a booklet, in order to contribute to the teaching of the safety in the nursing care to the hospitalized child and to the health education to the workers of pediatric units.

\section{METHOD}

Study is grounded on the theoretical methodological referential simbolic interacionism, considering this focus enables comprehension of the meaning that the subject attributes to the study's object. Meanings are constructed on social actors' daily life, such as actions and words that produce meaning for those involved and are shared by language. The proposal of simbolic interacionism, is "[...]; that meanings, symbols and language that gear social life are sought and that interactions and interconnections are investigated, because this is the best vision that one can have of the invidual, that is always interacting"10:183. Based on the aims the study is characterized as descriptive and may be considered, also, as applied, considering the aim of contributting for pratical ends.

Data collection, developed on the second semester of 2015, was developed by one of the researchers, through self-administered questionnaire to students of two nursing technician programs and of systematic observation of two pediatric units of two general hospitals. Semistructed questions created by the researchers, versed about knowledge about the patient safety six goals, delimitated by six based protocols from Ministry of Health (BR): patient identification; effective communication; safety in prescription, use and administration of medications; safe surgery; practice of hand hygiene in health services; and prevention of falls and pressure ulcer, that are part of Patient Safety National Program, which aims to prevent and reduce the incidence of adverse events on public and private health services. ${ }^{4}$

For systematic observation, a structured script, adapted from Lobão and Menezes instrument was used. ${ }^{11}$ The script versed about (un)safe situations/conditions to pediatric patient care.
Through previous contact with the management of nursing technician program and hospitals, data collection was started. The choice of places and subjects followed the criterion of accessibility. The research scenarios are located in the northwest region of the state of Rio Grande do Sul.

In order to facilitate the interaction with research patients' in the begining of data collection and before delivering the questionaire to students, the research was presented, explaining the aims and the training interface with safety culture. Contact with the students was done during the night shift for two days and the application of the questionnaire was given in the first period of class, with the consent of the teacher who was in the room at the time of collection. The duration of the questionnaire involved about $30 \mathrm{~min}$. To carry out the observation, two visits were made in each hospital, in view of the demand and agitation of the pediatric unit. The observation was made in an approximate time of 30 minutes at each visit.

The data were analyzed through content analysis of the speeches, in the thematic modality. From the analysis of the questionnaire, answers emerged that allowed the construction of a single thematic category: 'The safety of the hospitalized child in the perception of students of nursing technician program'.

After this stage, an educational booklet was elaborated, considering the requirement of the Professional Master's Program in Scientific and Technological Teaching. There was no intention to validate the booklet, using a specific methodology, which can be done in a later study, considering that it is not required in the said Program. In accordance with its Rules of Procedure, the product is validated by the examining board. The booklet focused on the six international patient safety goals and was based on the available and updated literature of the National Sanitary Surveillance Agency.

In compliance with the ethical requirements, the research project was sent to the Ethics Committee of the Integrated Regional University of Alto Uruguai and Missões, Santo Ângelo/ RS campus and approved, under the feedback no 1.227.226. Institution managers were offered a Statement of Coparticipant Institution and the subjects who agreed to participate were invited to sign the Free and Informed Consent Term. The subjects were identified by letters and numbers.

\section{RESULTS AND DISCUSSION}

Twenty two out of 47 sudents of nursing technician program participated in the study. There was no intention to separate the analysis by course, but to know the meanings of a group of students about the pediatric patient safety. Of these, $15(68,1 \%)$ had some experience caring for children.

Data analysis stage followed recommendations of qualitative approach, in the perspective of symbolic interacionism. Faced with the perceptions of the study participants, the meanings 
attributed by them to the safety of the pediatric patient were identified and interpreted; These meanings are constituted from the microinteractions of each one with his world of objects, throughout his social life journey. These meanings were grouped into one category.

\section{Hospitalized child safety in the perception of students from nursing technician program}

Of the participants, the great majority considers the hospital a safe environment for the care of the child and the reasons they have mentioned involve being in environments with medical and nursing resources and having adequate physical environment. It is observed that these meanings arise from previous concepts that are related to the function of a hospital institution that surround the life history and the interactions of the students and that are reinterpreted. The concept of adverse event manifested by the subjects included carelessness, unsafe act and error. The conceptualization was considered correct, since adverse events are related to incidents that result in harm to the patient. ${ }^{4}$

\section{Are the side effects or carelessness in the administration of medication or in the care. (E5)}

Adverse events may be medications that are given in the wrong way, either the route of administration or inadequate dilutions. (E7)

Wrong use of gloves, lack of hand hygiene, improper disposal of gloves, and very rapid infusion medications were incidents observed by students in child care that could cause harm. According to the current paradigm that involves the prevention and control of infections related to health care, the symbology attributed to the hygiene of the hands materializes the importance of cleanliness, tidiness, asepsis and the preservation of the well-being and health of the human body. The student learns in the course of the course and experiences in the microssocial space of clinical teaching practice.

Regarding hand hygiene, it was observed that the indications "before contact with the patient" and "before aseptic procedure" showed the lowest adhesion to hand hygiene, showing that it is the most fragile point in the care, and similar to a study carried out in southern Brazil. ${ }^{12}$ The same study suggests that it's necessary to promote change of attitude and work among infection control service, health professionals and other services, in an interdisciplinary and intersectorial way. This will only be possible with the union between managers, heads of areas and professional categories, to seek better results in hand hygiene. Even though the knowledge and awareness by developed campaigns, adherence to hand hygiene practice by health professionals is a challenge, ${ }^{12}$ especially in view of the multiresistance scenario of microorganisms, a worldwide risk to the safety of users of health services and workers.
On this practice the literature is vast, but it is important to emphasize the scarcity of studies on the hygiene of the hands by the parents of hospitalized children. A research ${ }^{13}$ that reviewed the scientific evidence on parental involvement in promoting hand hygiene in pediatric settings, identified that most have poor knowledge about hand hygiene indications but have recognized the practice as a relevant strategy for infection prevention associated with health care. In the same way, the practice of parents to remind health workers about hygiene is still low.

A systematic review ${ }^{14}$ that sought to evaluate the efficiency of interventions to prevent infections related to health care (IRHC) of developing countries, identified that most of studies were in South America and Asia and that, hand hygiene campagins integrated to other interventions show higher efficiency to reduce rates of IRHC. Of 34 studies of this review, only three demonstrated that hand hygiene campaigns alone reduced such rates. Multi-faceted interventions, including hand hygiene campaigns, rational administration of antibiotics and other elementary infection control practices are effective in developing countries.

As to the consequences of the observed adverse events, the study students on screen cited work accidents and patient reactions. It should be noted that mistakes concerning the administration of medications were cited by the majority as unsafe practices. Failures in drug administration reported by students were also observed by the researchers, especially regarding neglect of the use of the right nine in medication administration; lack of double checking protocol, insulin therapy and drug dilution. Observou-se, ainda, o uso de seringas sem dispositivos de segurança. Unsafe drug administration was the prevalent adverse event in media records, according to a study that aimed to analyze the adverse events occurring in nursing practice registered in the written media, between 2007 and 2012. ${ }^{15}$

Other actions that represented unsafe care, such as incorrect patient identification, inefficient communication, specially characterized by the lack of discusion of clinical condition of those hospitalized and incorrect notification of adverse events were identified, among other situations that denote institutional weakness to safety culture.

About the communication, hospitals have been discussed about the patient information transfer process from a professional to the other that, if ineffective is recognized as a serious risk in patient safety and one of the main causes of error. The same way, unsuccessful communications have been cited as one of the main factors that lead to errors in health scenarios. It is noted that communication is not only effective as the listener clearly understands the message the speaker sends. ${ }^{16}$

Implementation of educational programs is a fundamental element to excelence of a health institution and favours communication to discuss clinical cases and rational use of 
antimicrobials. The development of a remote telemedicine consulting program was a strategy used by a highly specialized pediatric cardiac hospital, which involved consultations for strategies for antibiotic use and biweekly discussion of all clinical cases, demonstrating a positive impact identified through a comparative study. There was a reduction in the rate of infection; in the general antibiotic cost and on the average used per admission. Significant decrease in the rate of isolation was observed in antimicrobial resistant patients. Strategies of this type have been an effective mechanism for economic and professional development in the multidisciplinary management of complex patients. ${ }^{17}$

Also during observation, some non conformities related to physical structure, to exposure of agents of physical, biological and accidentds risk were identified, specially that can focus on adverse events and/or harms. Observing these units had special significance for one of the researchers, considering their experience for more than a decade in child care settings and their concern for the safety of these small patients. Excessive heat and noise were observed in the rooms (from the power generator, since at one of the hospitals the unit is on the floor above the laundry). In addition, the unit serves as access to other sectors; children with different diseases in the same room, including transmissible; furniture not suitable for children, small space; lack of accommodation for mothers; lack of protection in outlets; screen protection grids replaced with screens; some unglazed beds and some protective grids of defective beds and disregarding the minimum requirements of functionality and safety (dimensions 1.40 to $1.90 \mathrm{~m}$ wide).$^{18}$

It was identified that the quantitative and qualitative of workers was insufficient; in moments of great demand in the clinical unit, there was hospitalization of adults in the same area of care for children. Some of these nonconformities may include falls and other accidents, exposure to communicable diseases, dehydration, irritability to the child, and others may facilitate errors, resulting in unsafe care.

Among other recommendations from RDC 50/2002, ${ }^{18: 38,39}$ and not observed in hospitalization units of adult and child patients must enable conditions for such, being in individual and collective envirornments, according the age, pathology, genre and intensivity of care; and if child, must "[...] develop activities of child recreation and occupational therapy; and have child pegagogical care (elementary school) when the time of hospitalization are more than 30 days".

It is understood that, when avoiding agitation of many children in the same room at the time of care, or the hodgepodge of adult and child patients, the better the concentration and the lower the possibility of errors of the health team. Having individual beds or infirmaries with few beds is a conformation that favors comfort and safety, the team's interaction with the family, as well as contributes to the physical, psychological, social and pedagogical needs of the child.
Aiming to reduce incidence of falls in pediatric patients, using multilanguage poster about prevention of falls, that was strategic positioned low all cribs in a pediatric uit, served as an effective reminder and a communication method between the care team and family members. Awareness of caretakes and knowledge of preventive methods contributed to decrease of $50 \%$ of incidence of fall in patients up to 3 years old, in comparison with incidence rate in $2010 .{ }^{19}$

As for the strategies to guarantee the safety of the hospitalized child, the participants of the study on screen mentioned, with regard to training, more practices and stages and, in the hospital practice, they quoted more frequently: constant updating, a team of professionals with a profile to care for of children, strict adherence to prescription and safety in the unit both in physical area and in working conditions. The guidance of parents was cited by some as central to the safety of hospitalized children.

Security screens on windows and security in the unit, not only in the concierge. (E7)

Guidance for mothers and professionals trained for pediatrics. (E9)

A review study ${ }^{20}$ showed that contribution of parents in patient safety associated to the need to survaillance their children care, to guarantee that errors wouldn't occur. In general, parents are motivated to report on the safety of care provided and can provide key data. Collaborative work among the team, the patient, and the family has the potential to reduce the child's anxiety and to favor the satisfaction of both the patient and the family.

In order to improve teaching for the safety of hospitalized children, all participants expressed curricular weaknesses and the need for more practical classes aimed at the safety of hospitalized children. A discipline focused on patient safety has also been suggested by some. It should be noted that the variable 'more practical classes' was doubly quoted, either to guarantee the safety of the hospitalized child or to qualify teaching.

More practical classes can mean more social interaction, characterized by the process of exchanging messages between colleagues and teachers, of experiences for the learning process, of the relationships that occur within groups and institutions. The symbolic interaction, in this case, is directly linked to the pedagogical act that makes sense to them, in a kind of reaction to the social stimuli required as a future professional. Here the practical classes constitute a social dynamic that functions as a strategy for empowerment and autonomy.

Following some quotes:

Children are always patients of immediate attention: in my opinion the focus should be bigger [in classes] in relation to the practice of medication administration. (E6) 
Beyond illnesses that can occur during that phase that were studied, it would be interesting if subjects related to child safety while hospitalized were approached [in classes] with more practical classes. (E8)

It is necessary to advance teaching in the theme, on formal spaces. A research using documents, interviews, focus groups with educators, students, health professionals, patients and stake holder and observation of students of eight university courses of health, identified that, in general, patient safety theme was implied in curricula and, in only a restrict number of areas was identified explicitly. Learning about these issues predominantly in isolation, generating scarce opportunities for interprofessional learning and for the relationship between educational, practical and political contexts. Professionals who serve as models for students in the area of patient safety and who are fundamental to learning, according to the participants, exist in limited numbers. ${ }^{21}$

Proposals for Permanent Education in Health (PEH) with professionals from the services, professors and studetns can aggregate value to safe care as the power can be a facilitator to incorporate structure change of work and teaching. It is emphasized that traditional courses that disregard work-learning, nor the context of the place, have no effect in the daily life of the services. PEH processes fundamented in problematizing practices based on learnings articulated with the work envirornment, conceiving the action-reflection-action focused on guiding are essential to learning and work relationships. The main benefit of these practices in services is associated with open dialogue in conversation circles, consituted by "discussion groups with positive affirmations related to work commitment, strenghtening teaching-service integration, preparing the professional through the development of critical, creative capacity and pro-active posture". $22: 180$

Asked about their beliefs about the importance of an educational booklet as a safe child support, all participants referred to it as a positive initiative. They believe that the primer will serve as a problem-solving supply to support nurse management and as a 'standardized protocol' for safe care.

It informs all; it's like a protocol to child care where all would have access and bosses could charge their team, because they would have support the material has. (T7).

After analyzing the questionnaire and systematic observation data, an educational product was developed since it is a requirement of the Master's program. The product in question is a booklet, based on the scientific literature. This proposal emerged from the contribution of the students and systematic observation. We chose to explore the six goals for patient safety ${ }^{1,4}$ stabilished by the Ministry of Health. Thus, the booklet deals with the safety of the hospitalized child, regarding the identification of the child, effective communication, adequate use of medicines, safe surgery, hand hygiene, reduction of risk of falls and pressure ulcers, according to Ministry of Health targets.

Printed educational materials are widely used for the dissemination of information and to facilitate the teaching-learning process. We sought to comply with the recommendations for the elaboration of these materials, such as research on the subject, transform the language of the information found in the literature, making it accessible to the target audience; select important and meaningful information on the subject; make the material attractive, objective, not very extensive and easy to understand and qualify the material, which presupposes the evaluation of the material built. Illustrating the guidelines is an important recommendation, considering that it relaxes, encourages and fosters understanding. ${ }^{23}$

The preliminary version of the booklet was submitted to the students' evaluation of one of the nursing technician program, by invitation to all the students who participated in the initial stage of data collection, whose meanings attributed to teaching about pediatric patient safety contributed to the construction from the booklet.

In the day and hour agreed with the participants were presented the results of the analysis and the booklet for discussions and possible changes, by means of a conversation wheel next to the subjects, who opined, through a form, on concordances, disagreements, positive points and points to improve in layout, content, language, illustrations, format or other. It was decided not to systematize the evaluation, so that, freely the students could demonstrate the meaning of this material to them, the meaning represented. Subjects were offered a printed version so that they could handle the material. The impressions expressed were very positive and, in view of its recommendations, some items were altered in order to qualify the educational material. In order to record the activity, a report was prepared.

All attributed positive meanings to content and language, classifying them as clear, comprehensible. The contents were highly praised by the participants, who considered them practical and of the size/extension necessary for quick consultations or for permanent education. Illustrations and format were considered to be.

Some suggestions for qualifying the booklet were pointed out, such as including, on the identification bracelet, item on allergy to medication or food; review repeated words; replace some words; reviewing the source of a set of general recommendations, among others, which have taken into account adjustments to the suggested recommendations.

Here is the Booklet Archetype, divided into Figure 1; Figure 2; Figure 3; Figure 4 and Figure 5. 
Figure 1. Booklet Archetype. Source: the authors, 2016.
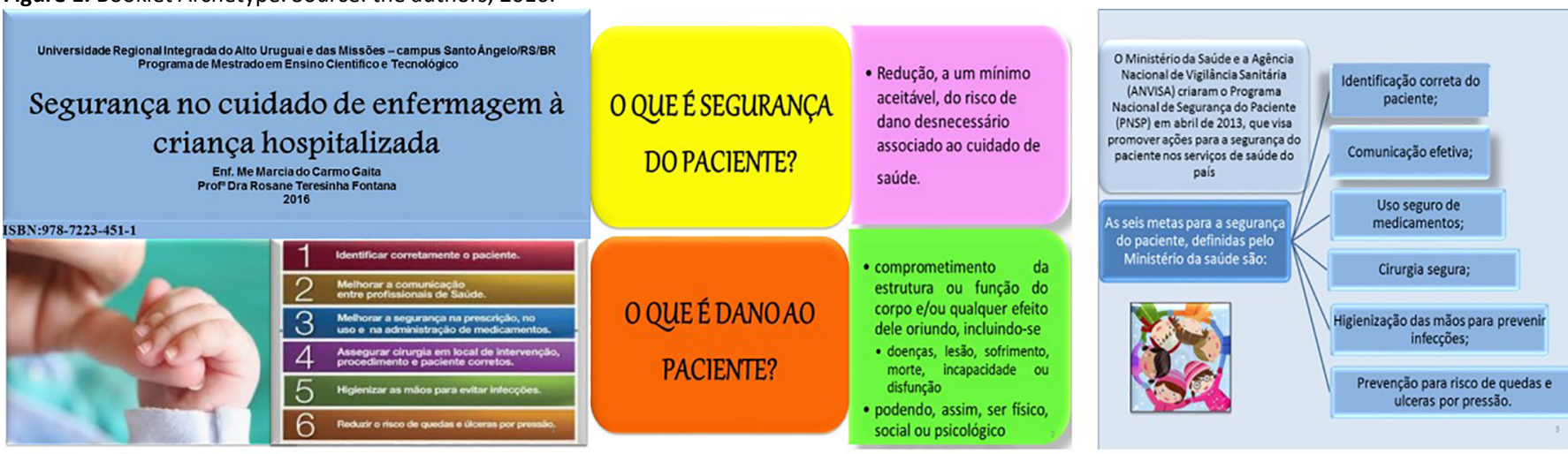

Protocolos para Segurança do Paciente

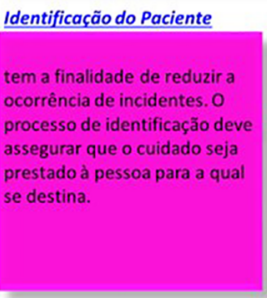

Prevenção de Úlcera por Pressão

visa a prevenir a ocorrência dessa e de outras lesões da pele, visto que é uma das hospitais. Sua incidência hospitais. Sua incidência combinação de fatores de riscos, entre de fatos, idade riscos, entre eles, idade pele, visto que é uma das da longa permanência em

social ou psicológico

\begin{tabular}{|c|c|}
\hline \multicolumn{2}{|c|}{ Protocolos... } \\
\hline $\begin{array}{l}\text { Prática de Higiene das Mãos em } \\
\text { Serviços de Saúde. }\end{array}$ & Prevenção de Quedas \\
\hline $\begin{array}{l}\text { aborda informações sobre a } \\
\text { instituiçäo e promoção da } \\
\text { higiene das mãos nos serviços } \\
\text { de saúde do pais. Seu intuito é } \\
\text { prevenir e controlar as } \\
\text { infecç̧es relacionadas à } \\
\text { assistência à saúde (IRAS), } \\
\text { visando à segurança do } \\
\text { paciente, dos profissionais de } \\
\text { saúde e de todos aqueles } \\
\text { envolvidos nos cuidados aos } \\
\text { pacientes. }\end{array}$ & $\begin{array}{l}\text { tem como meta reduzir a } \\
\text { ocorrenncia de queda de } \\
\text { pacientes nos pontos de } \\
\text { assistência e o dano dela } \\
\text { decorrente, por meio da } \\
\text { implantacăo/implementação } \\
\text { de medidas que contemplem a } \\
\text { avaliação de risco do paciente, } \\
\text { garantam o cuidado } \\
\text { multiprofissional em um } \\
\text { ambiente seguro e promovam } \\
\text { a educaçăo do paciente, } \\
\text { familiares e profissionais. }\end{array}$ \\
\hline
\end{tabular}

Figure 2. Booklet Archetype. Source: the authors, 2016.

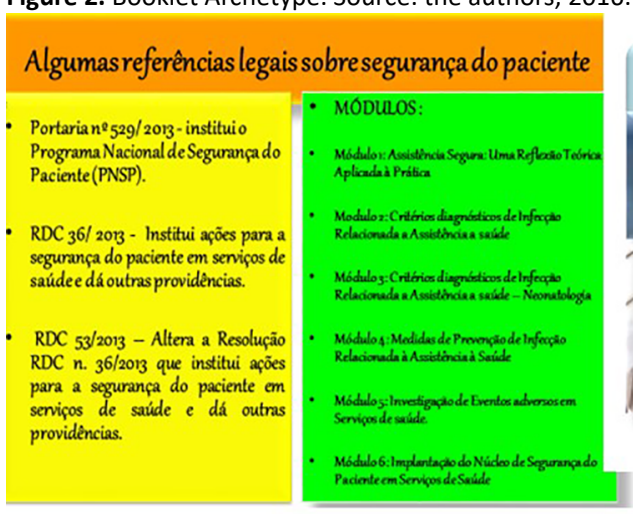

Sequrança na Prescrição, Uso, e objetiva a promoção de práticas seguras no uso de medicamentos em estabelecimentos de saúde. Segundo o protocolo, estima se que os erros de medicação em hospitais provoquem mais de sete mil mortes por ano nos Estados Unidos, acarretando custos tangiveis $\mathrm{e}$ intangiveis

\section{rotocolos}

Cirurgia Segura diz respeito ao estabelecimento de medidas a serem implantad para reduzir a ocorrência de mortalidade cirúrgica, possibilitando o aumento da segurança na realização de procedimentos cirúrgicos, no local correto e no paciente correto, por meio do uso da Lista de Verificação de Cirurgia Segura desenvolvida pela OMS.

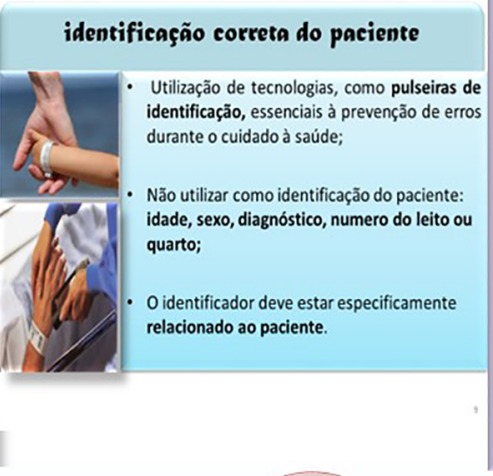

UTILZAR NO MÍNIMO DOIS IDENTIFICADORES, COMO:

- Nome completo do paciente;

- Nome completo da mãe do paciente;

- Data de nascimento do paciente;

- Número de prontuário do paciente ;

A confirmação da identificą̧ão do paciente será realizada antes de qualquer cuidado que inclui:

- Aadministractao de medicamentos A administraçado do sangue - Andministrapato dehemoderivados

A coleta de matrinal por

- Aentroga da dictac

mtosinasive
Independentemente do metodo adotado para produzir os identificadores, a ler e durável.

A pulseira deve ser deve ser de cor branca e adequar-se ao perfil do paciente;

O material da pulseira deve ser flexível, liso, impermeável, laváve ehipoalergentico;

A pulseira de identificação não deve agarar na roupa, no equipanento ou nos dispositivos, inclusive nos acessos venosos não aderir a pele.

\section{comunicação efetiva}

A troca de informações, a disseminação de boas ideias e resultados entre os diferentes setores do hospital são necessários para envolver as equipes e promover a cultura de necessários
segurança.

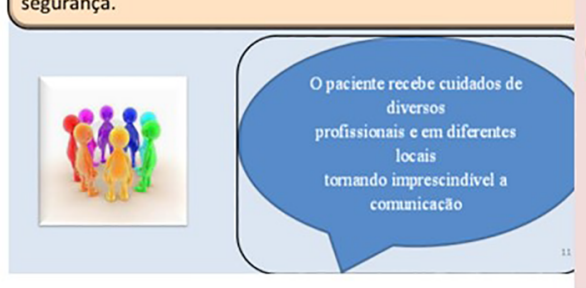

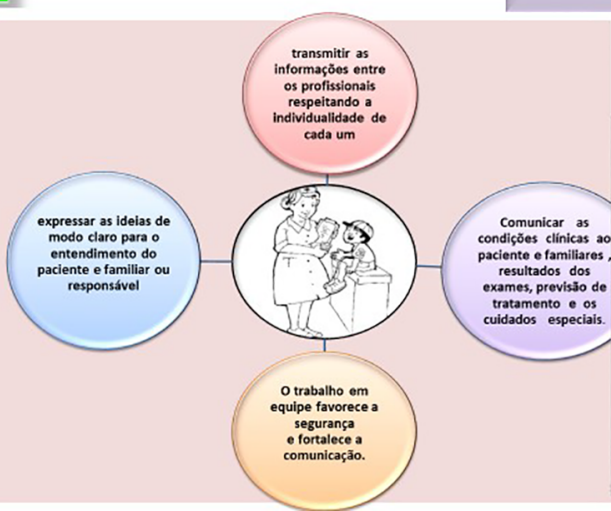

uso seguro de medicamentos

13 CERTOS DA MEDICAÇÃO SEGURA

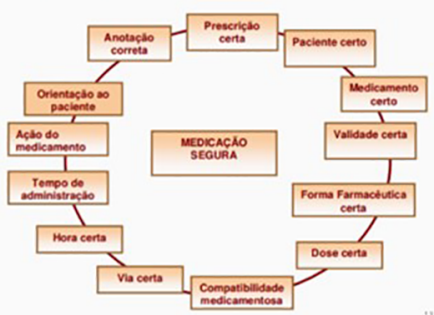


Pediatric Patient Safety

Gaita MC, Fontana RT

Figure 3. Booklet Archetype. Source: the authors, 2016.

\section{- Outras recomendações:}

- Medicamentos trazidos de casa: Investigar com a familia para verificar continuidade ou não do uso do mesmo;

- Nãotransferirpara of familiar a responsabilidade do cuidado;

- Alergia: verificar histórico antes da administração da medicação;

- Atenção a siglas e abreviaturas na prescrição e registros, pois podem gerar interpretação ambígua;

- Atenção a medicamentos com nomes semelhantes e expressão de medidas (ampola, frasco, microgotas...);

- Rótulos devem ser completos;

- Usar cateteres, sondas e seringas com dispositivos que previnam conexão incorreta ou desconexão acidental;

- Os erros devem ser notificados ao Núcleode Segurançado Paciente.

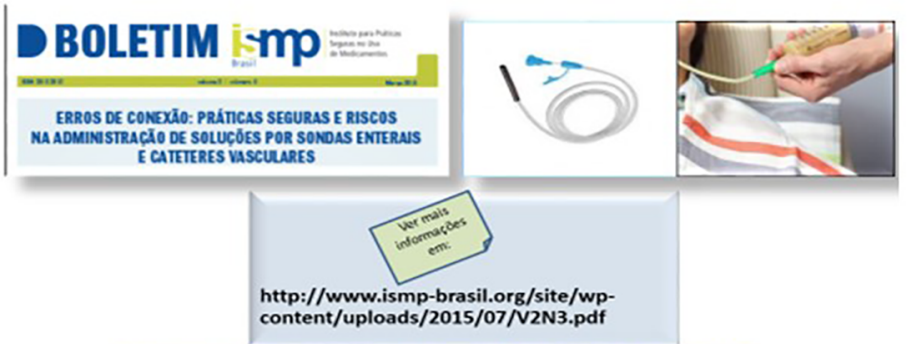

RECOMENDAÇOES GERAIS PARA A PREVENĢAO DE ERROS DE CONEXAO

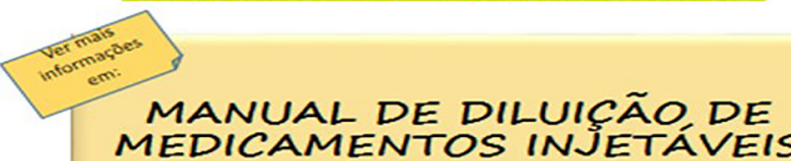

httpis/wwwhusmufsmibr/janelat Inanual-de-medicacaopd

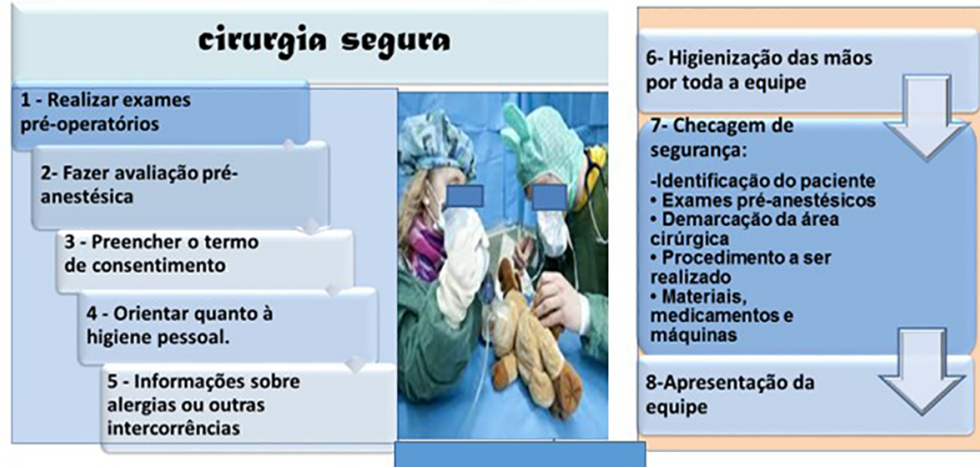

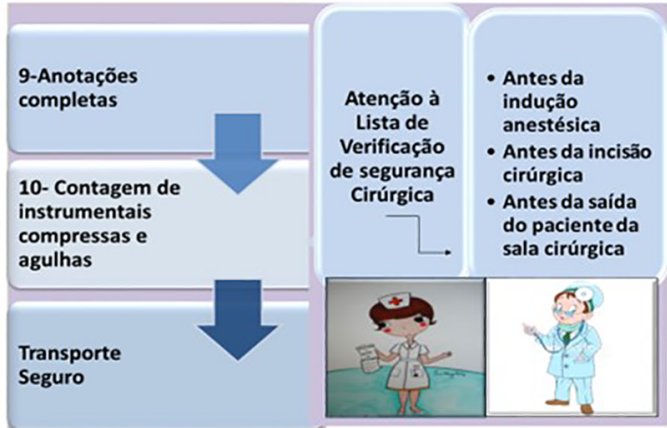

Figure 4. Booklet Archetype. Source: the authors, 2016.

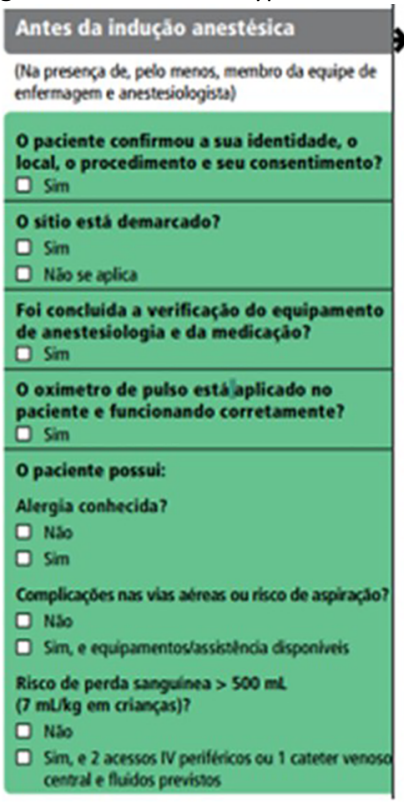

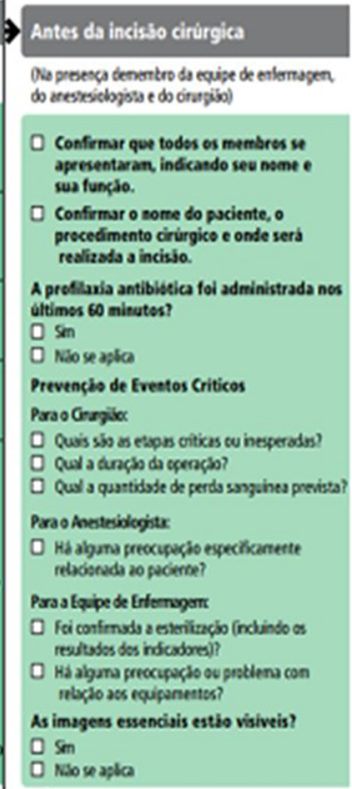

\section{Antes da saida do paciente da sala cirurgica}

(Na perseeca do mentro da equice de entermogen, do anestesislogista e do cinurgijso)

A equipe de enfermagem confirma verbalmente:

$\square$ onome ds procesimento

- A cendusbo da cortagen de instrumentos. compressas aguhas

A A identificoço das amostus fler os rotulos das anostras en voc alta, indusive o nome do pocientel

口 Se hà quaisques problenas con or equipamentos a serem resavidos

\section{Para o Cinurgito, o Anestesiobogista e a} Equipe de Enfermagem

Q Quas sio as pencipais prescupacbes pan a recuperaças e o manejo do paciente?

Rev. Latino-Am. Enfermagem Maria Paula de Oliveira Pires 21(5):[08 telas]

set.-out. 2013

wnwceerp.usp.br/rlae

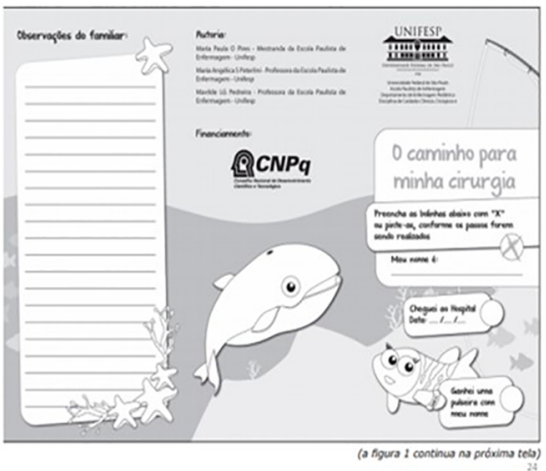

Mavilde da Luz Gonçalves Pedreira

Maria Angélica Sorgini Peterlini

Cirurgia segura em pediatria: elaboração e validação de checklist de intervenções pré-operatórias 
Figure 5. Booklet Archetype. Source: the authors, 2016.

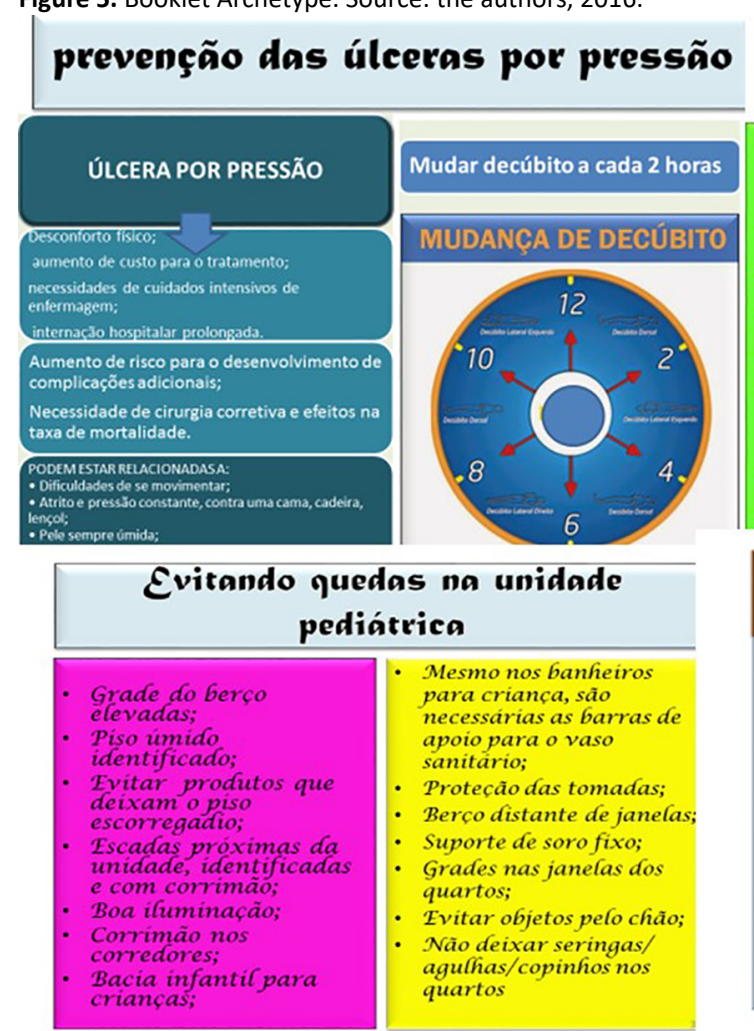

\section{FINAL CONSIDERATIONS}

Results showed observations, conceptions, feedback and knowledge from studetns that are, in general, compatible with what is reported in the literature on the subject. For some, the adverse event and/or unsafe care was associated with precarious working conditions, a situation that may be attached more to the cause of the error than to the consequence. Incorrect medication administration was one of the significant points pointed out by the study as an incident capable of causing damages, followed by risk of falls and accidents, due to the poor arrangement in the windows and bars of the cribs/beds, unsuitable for the safety of the child, among others. One negative factor identified and of considerable importance for the safety of the infantile patient was the lack of exclusive unit for the care of the hospitalized child in one of the units.

Many students have cited the lack of a specific discipline that addresses the issue and the lack of continuous practices on drug dilution. Drug administration, patient identification, hand hygiene, the possibility of falls and communication were therefore the main weaknesses in the units investigated. There is a need to construct a new physical space and to resize the nursing team and processes of permanent education in health, with emphasis on team management and macrogestión, focusing on the guidelines on patient safety and the implementation of nuclei, safety culture.
As for the booklet is believed in its potential to promote education. During the talk round, positive statements were made about the importance of the booklet as a tool that can help in updating knowledge to the safety of hospitalized children. It is worth emphasizing that the construction of learning objects does not replace the role of students and teachers in the teaching and learning process, but they can stimulate and lead the process in a collaborative way, develop and compose classes in a structured and organized way, besides contributing for student autonomy and for meaningful learning. The creation and use of these tools in nursing teaching should be encouraged, transforming them into active and innovative methodologies.

Training institutions and class organs should unite to build a safer nursing, both regarding the working conditions of the team, as well as the training of workers, focusing on both the quality and the healthy environment of the work place of the work scenarios. health, and in constitutive actions of teaching and learning focused on methodologies that ratify the importance of the theme. It should be emphasized in studies of this nature that labor institutions should offer their workers decent pay, so as to minimize a common phenomenon in nursing that is a double work day, a fact that leaves the worker vulnerable to errors with consequences, often fatal. The training of workers for the safety culture, together with adequate working conditions and attention to the health of the worker in the health environments, can qualify the care to the user of the services. 
The limitations found for the study were related to observation by the demand for work, a situation that contributed to the need to change the schedule regarding data collection, but without prejudice to the study.

Further studies on the safety of the hospitalized child, as well as on the care of the child in the basic health care space, still scarce in the national literature, are suggested. Studies on pediatric unit physical area compatible with safe care is also a gap to be studied.

\section{REFERENCES}

1. Ministério da Saúde (BR). Fundação Oswaldo Cruz. Agência Nacional de Vigilância Sanitária. Documento de referência para o Programa Nacional de Segurança do Paciente. Brasília (DF): Ministério da Saúde; 2014.

2. Pedreira MLG. Enfermagem para a segurança do paciente. Acta Paul Enferm [Internet]. 2009;22(4):v-vi. Available from: http://dx.doi. org/10.1590/S0103-21002009000400001

3. Andrade PP, Amaral TS, Omizzolo JAE. Segurança do paciente: administração segura de medicamentos. Rev Inova Saúde [Internet] 2015;4(2):45-60. Available from: http://periodicos.unesc.net/ Inovasaude/article/view/1948/0

4. Ministério da Saúde (BR). Portaria № 529, de 1ํ de abril de 2013. Institui o Programa Nacional de Segurança do Paciente (PNSP). Brasília (DF) Ministério da Saúde; 2013.

5. Wegner W, Pedro ENR. A segurança do paciente nas circunstâncias de cuidado: prevenção de eventos adversos na hospitalização infantil. Rev Latino Am Enferm [Internet]. 2012 May/Jun;20(3):427-34. Available from: http://dx.doi.org/10.1590/S0104-11692012000300002

6. Ministério da Saúde (BR). Agência Nacional de Vigilância Sanitária Boletim Segurança do Paciente e Qualidade em Serviços de Saúde № 15: Incidentes Relacionados à Assistência à Saúde 2016. Brasília (DF): Ministério da Saúde; 2016

7. Predebon CM, Silva SC, Olaves FS, Kantorski KJC, Pedro ENR, Wegner W. Perfil das notificações de incidentes analisados pela comissão de qualidade e segurança pediátrica. In: ANAIS - I Congresso Internacional da Rebraensp. [Internet]. 2016 [cited 2016 Nov 5]. Available from: https:// www.lume.ufrgs.br/bitstream/handle/10183/140646/000991213. pdf?sequence $=1$

8. World Health Organization - WHO. World Alliance for Patient Safety. WHO patient safety curriculum guide: multi-professional edition [Internet]. Geneva: World Health Organization; 2011. [cited 2015 Dec 8]. Available from: http://apps.who.int/iris/ bitstream/10665/44641/1/9789241501958_eng.pdf

9. Ministério da Educação (BR). Referenciais Curriculares Nacionais da Educação Profissional de Nível Técnico. Brasília (DF): Ministério da Educação; 2000.

10. Correa AS. Interacionismo simbólico: raízes, críticas e perspectivas atuais. Rev Bras Hist Ciênc Soc [Internet]. 2017 Jun; [cited 2018 Jun 23]; 9(17):176-200. Available from: https://www.rbhcs.com/rbhcs/ article/view/343

11. Lobão WM, Menezes IG. Construction and content validation of the scale of predisposition to the occurrence of adverse events. Rev Latino Am Enferm [Internet]. $2012 \mathrm{Jul} /$ Aug;20(4):796-803. Available from: http://dx.doi.org/10.1590/S0104-11692012000400021

12. Souza LM, Ramos MF, Becker ESS, Meirelles LCS, Monteiro SAO. Adesão dos profissionais de terapia intensiva aos cinco momentos da higienização das mãos. Rev Gaúcha Enferm [Internet]. 2015;36(4):21-8 Available from: http://dx.doi.org/10.1590/1983-1447.2015.04.49090
13. Bellissimo-Rodrigues F, Pires D, Zingg W, Pittet D. Role of parents in the promotion of hand hygiene in the paediatric setting: a systematic literature review. J Hosp Infect [Internet]. 2016 Jun;93(2):159-63. Available from: https://www.ncbi.nlm.nih.gov/pubmed/?term=Role +of+parents+in+the+promotion+of+hand+hygiene+in+the+paed atric+setting $\% 3 \mathrm{~A}+\mathrm{a}+$ systematic+literature+review. DOI: 10.1016/j. jhin.2016.02.001

14. Murni I, Duke T, Triasih R, Kinney S, Daley AJ, Soenarto Y . Prevention of nosocomial infections in developing countries, a systematic review. Paediatr Int Child Health [Internet]. 2013 May;33(2):61-78. Available from: https://www.ncbi.nlm.nih.gov/pubmed/23925279.DOI 10.1179/2046905513Y.0000000054

15. Fontana RT, Wolf J, Rodrigues FCP, Castro LM. Análise documenta da mídia escrita sobre eventos adversos ocorridos na prática da enfermagem. Rev Enferm UFPE On Line [Internet]. 2015 May; [cited 2017 Feb 7]; 9(Supl. 4):8103-10. Available from: https://periodicos.ufpe. $\mathrm{br} / \mathrm{revistas/revistaenfermagem/article/viewFile/10565/11498}$

16. Vanderbilt AA, Pappada SM, Stein H, Harper D, Papadimos TJ Increasing patient safety with neonates via handoff communication during delivery: a call for interprofessional health care team training across GME and CME. Adv Med Educ Pract [Internet]. 2017; [cited 2017 Jun 20]; 8:365-7. Available from: https://www.ncbi.nlm.nih.gov/ pubmed/28652839. DOI: 10.2147/AMEP.S129674. eCollection 2017

17. Ceradini J, Tozzi AE, D'Argenio P, Bernaschi P, Manuri L, Brusco C et al. Telemedicine as an effective intervention to improve antibiotic appropriateness prescription and to reduce costs in pediatrics. Ital $\mathrm{J}$ Pediatr [Internet]. 2017 Nov 17;43(1):105. Available from: https://www. ncbi.nlm.nih.gov/pubmed/?term=Telemedicine+as+an+effective+inte rvention+to+improve+antibiotic+appropriateness+prescription+and+t o+reduce+costs+in+pediatrics. DOI: 10.1186/s13052-017-0423-3

18. Ministério da Saúde (BR). Resolução da Diretoria Colegiada № 50 , de 21 de fevereiro de 2002. Dispõe sobre o Regulamento Técnico para planejamento, programação, elaboração e avaliação de projetos físicos de estabelecimentos assistenciais de saúde. Brasília (DF): Ministério da Saúde; 2002.

19. Lee YL, Yip WK, Goh BW, Chiam EP, Ng HP. Fall prevention among children in the presence of caregivers in a pediatric ward: a best practice implementation. Int J Evid Based Healthc [Internet]. 2013 Mar; [cited 2017 Jun 13]; 11(1):33-8. Available from: https://www.ncbi.nlm.nih.gov/ pubmed/?term=Fall+prevention+among+children+in+the+presence+ of+caregivers+in+a+paediatric+ward\%3A+a+best+practice+impleme ntation. DOI: 10.1111/1744-1609.12003

20. Wegner W, Silva MUM, Peres MA, Bandeira LE, Frantz E, Botene DZA, et al. Segurança do paciente no cuidado à criança hospitalizada: evidências para enfermagem pediátrica. Rev Gaúcha Enferm [Internet] 2017 May;38(1):e68020. Available from: http://www.scielo.br/scielo. php?script=sci_arttext\&pid=S1983-14472017000100504. DOI 10.1590/1983-1447.2017.01.68020

21. Cresswell K, Howe A, Steven A, Smith P, Ashcroft D, Fairhurst K, et al Patient Safety Education Research Group. Patient safety in healthcare preregistration educational curricula: multiple case study-based investigations of eight medicine, nursing, pharmacy and physiotherapy university courses. BMJ Qual Saf [Internet]. 2013 Oct; [cited 2017 Jul 20]; 22(10):843-54. Available from: https://www.ncbi.nlm.nih.gov/ pubmed/23728120 DOI: 10.1136/bmjqs-2013-001905

22. Miccas FL, Batista SHSS. Educação permanente em saúde: metassíntese. Rev Saúde Pública [Internet]. 2014;48(1):17085. Available from: http://www.scielo.br/scielo.php?pid=S003489102014000100170\&script=sci_abstract\&tlng=pt. DOI: 10.1590/ S0034-8910.2014048004498

23. Echer IC. Elaboração de manuais de orientação para o cuidado em saúde. Rev Latino Am Enferm [Internet]. 2005 Sep/Oct; [cited 2018 Jun 23]; 13(5):754-57. Available from: http://dx.doi.org/10.1590/S010411692005000500022 